\title{
RAPD Analysis for Genetic Variability Detection of Mutant Soybean (Glycine max (L.) Merr)
}

\section{Didik Wahyudi ${ }^{*}$, Lia Hapsari ${ }^{2}$, Sundari ${ }^{3}$}

1) Biology Department, Faculty of Science and Technology, State Islamic University of Maulana Malik Ibrahim, Malang, St. Gajayana No. 50 Malang, East Java, 65144, Indonesia.

2) Purwodadi Botanic Garden - Indonesian Institute of Sciences, St. Raya Surabaya - Malang Km 65, Purwodadi, Pasuruan, East Java 67163, Indonesia

3) Department of Biology Education, Universitas Khairun, St. Pertamina Kampus II Unkhair Gambesi City of South Ternate, North Maluku Ternate 97719, Indonesia

Submitted: 22 January 2020; Accepted: 03 March 2020; Published: 15 April 2020

\begin{abstract}
This study aimed to detect and evaluate the genetic mutation from mutagenized soybean by RAPD markers. Soybean seeds of "Grobogan" variety were treated with two different concentrations of EMS $(0.5 \%$ and $1 \%)$ and three incubation times (4, 6 and $8 \mathrm{~h}$ ). DNA whole-genome was isolated from young leaf seedling with the Qiagen DNeasy Plant Mini Kit. Twenty OPA primers (OPA-1 to OPA-20) were used for DNA amplification. The results showed that EMS treatments successfully generated genetic variation in soybean, which indicated by high values of PIC, EMR, and MI. RAPD primers that effective to detect the mutation were OPA-2, OPA-07, OPA-10, OPA-11, OPA12, OPA-13, OPA-14, OPA-15, OPA-16, OPA-18 and OPA-20. The band expression of those primers was exhibited a stronger intensity along with increasing of EMS concentration and incubation time used in this study. Treatment of $0.5 \%$ EMS in 6 hours incubation was successfully generated soybean mutants with the lowest genetic similarity compared to the wild-type. Thus, this study provides a new approach to generate genetic variability in soybean and has the potential to improve for soybean breeding program.
\end{abstract}

Keywords: ethyl methane sulphonate, genetic mutation, RAPD, soybean.

\section{INTRODUCTION}

Soybean is one of the major foods crops commodities and can be considered as the cheapest source of protein in Indonesia (Setiawan, 2013). The productivity of soybean in Indonesia was still low and less profit if compared to rice and corn. This may be due to the lack of development and attention of soybean seed industry, land optimization, pricing policy for locals, exporters, and importers in the market (Kristanti et al. 2017). Furthermore, more than $60 \%$ of Indonesia's soybean consumption is still needed to be imported during 2012 - 2016 (Pusdatin, 2015; Wulandari, 2016). Therefore, The Indonesian government in 2015 has optimized the soybean farmland to enhance domestic soybean production (Suherman, 2014). However, about 40\%

\footnotetext{
*Corresponding author

Tel.: +6285649919880

Email: didik_wahyudi@bio.uin-malang.ac.id

(C) 2020, J. Tropical Biodiversity Biotechnology (CC BY-SA 4.0)
}

of the soybean farmland is considered as suboptimal and drylands (Balitbangtan, 2005; Wulandari, 2017).

Optimization of dry land for soybean farming has many challenges, especially the limited availability of soybean genotypes which tolerate the drought stress. Increasing the variability and adaptability of soybean by mutation breeding, and followed by selection may become one of the methods to solve the problem. Mutation breeding has been used in recent years as an alternative technique in generating new variability and development of crop species and varieties (Khan and Tyagi, 2013). One of the soybean varieties that have high yielding is Grobagan. Furthermore, Grobogan varieties have early maturity (76 days) and larger pod (Krisdiana, 2013)

Genetic mutations can be induced by chemical mutagenic agents using some mutation reagents (Oladosu et al. 2016) and physic mutagens by gamma rays, x-rays, and ultraviolet (Soeranto et al. 2001; 
Aisyah et al. 2005; Sreeju et al. 2011). Genetic mutations in soybean crops have been shown to increase the germination rate, viability, survival, yield, quality contributing characters such as pod setting, branching, protein, and oil content, also resistant to drought and diseases (Khan and Tyagi, 2013).

Ethyl Methane Sulfonate (EMS) is an alkylating chemical mutagen that has been shown effectively causes a high frequency of gene mutation. At low concentration, EMS generates $\mathrm{G} / \mathrm{C}$ to $\mathrm{C} / \mathrm{G}$ or $G / C$ to $T / A$ transversion, or $A / T$ to $G / C$ transition by pairing errors of 7 -ethylguanine and 3ethyladenine, respectively. Based on codon usage, EMS may also induce nonsense and missense mutations (Behera et al. 2012). If compared to other mutagens, genetic mutations induced by EMS were proven to be more effective than gamma rays in rice, lentil, mungbean (Singh et al. 2001), pea (Shah et al. 2009) and urad bean (Thilagavathi and Mullainathan, 2009). In addition, mutations using EMS in pea (Girija et al. 2013) and soybean (Khan and Tyagi, 2010) also caused mutations higher than the combination of gamma rays and EMS.

Recently, the effective detection of induced genetic mutations is still difficult to be measured. Many laboratories could not afford it since it is a very lengthy task, and due to spatial and technical limitations. Mutation detection in plants can be performed through phenotypic and genetic approaches. However, mutation detection using the phenotypic approach has many limitations and generated non-fixed character (Garcia et al. 2016). Therefore, the utilization of the genetic approach becomes a more reliable method and suitable for early mutation detection in the plant. Some genetic approaches which can be used for mutation detection are Random Amplification Polymorphic DNA (RAPD) (Ashraf et al. 2007), Restriction Fragment Length Polymorphism (RFLP), InterSimple Sequence Repeat (ISSR) (Mishra et al. 2014), DNA sequences (Wahyudi et al. 2013; Nikmah et al. 2016), etc.

RAPD based detection of genetic polymorphism is a molecular marker that is based upon a variation of the primer annealing sites in polymerase chain reaction/PCR. Primers were modified by even a single nucleotide which produces different banding patterns to detect genetic polymorphisms (Behera et al. 2012). It is a genetic marker which commonly used for mutation detection (Ashraf et al. 2007) and genetic variation study (Sundari et al. 2017; Kawar et al. 2009). RAPD marker has proven to be more reproducible than another genetic marker such as ISSR and RFLP; and no need to know the background of the genome being analyzed (Kumari and Thakur, 2014). The previous study proved that RAPD had been successfully used for mutation detection in rice (Ashraf et al. 2007), melon (Daryono et al. 2011), and sugarcane (Kawar et al. 2009).

In the present study, the seeds of soybean "Grobogan" variety were subjected to EMS-induced mutagenesis with combination treatments of different concentrations and incubation time to create variability. This study was aimed to detect and evaluate genetic mutation occurred in generated mutants seedlings of soybean, compared to the wildtype using RAPD marker. The finding of this study was expected to be useful in supporting the soybean breeding researches in Indonesia.

\section{MATERIALS AND METHODS}

\section{Plant Material}

Plant material used in this study was soybean "Grobogan" variety. It was obtained from Grobogan District, Central Java and released in 2008 by Grobogan District Local Government, Seed Control and Certification Service of Central Java and Central Java Province Local Government as superior soybean variety (Decreed 238/Kpts/ SR.120/3/2008). The superiorities of soybean "Grobogan" variety is early matured (76 days), large seed size (about $18 \mathrm{~g} / 100$ seeds), and tolerant in fed rain dry land; with a potential yield up to 4.2 tonnes/ ha (Rahajeng and Adie, 2013; Balitkabi, 2016; Balitbangtan, 2016).

\section{Soybean mutation induction by EMS}

A total of 40 Grobogan varieties soybean seeds were used in this study. About 30 soybean seeds were previously soaked in $40 \mathrm{ml}$ of phosphate buffer 100 $\mathrm{mM}$ at $4{ }^{\circ} \mathrm{C}$ for $24 \mathrm{~h}$. Then, it was added with new $40 \mathrm{ml}$ phosphate buffer $100 \mathrm{mM}$ and treated with a combination of 2 variations of EMS concentration $(0.5 \%$ and $1 \%)$ and 3 variations of incubation time (4, 6 and $8 \mathrm{~h}$ ). The combination of treatments are as follows: 1) 5 seeds soaked with $0.5 \%$ EMS and incubated for $4 \mathrm{~h}$; 2) 5 seeds soaked with 1\% EMS and incubated for $4 \mathrm{~h}$; 3) 5 seeds soaked with $0.5 \%$ EMS and incubated for $6 \mathrm{~h}$; 4) 5 seeds were soaked with 1\% EMS and incubated for $6 \mathrm{~h}$; 5) 5 seeds soaked with $0.5 \%$ EMS and incubated for $8 \mathrm{~h}$ and 6 ) 5 seeds soaked with 1\% EMS and incubated for $8 \mathrm{~h}$. The 10 seeds left was soaked with aquadest for 24 hours as a control group.

After treatment, the EMS-induced mutant soybean seeds and control were sown on the germination tray. On 30th days after sown, each seedling was transplanted in a polybag containing growing media, i.e. sands, husks, and composts. The 
Table 1. DNA sequences, GC content and annealing temperature of OPA primers used in this study

\begin{tabular}{cccc}
\hline Primer & Sequences ('5-‘) & GC Content $\mathbf{( \% )}$ & $\mathbf{T}_{\mathbf{A}} \mathbf{( { } ^ { \circ } \mathbf { C } )}$ \\
\hline OPA-01 & CAGGCCCTTC & 70 & 36.4 \\
OPA-02 & TGCCGAGCTG & 70 & 40.7 \\
OPA-03 & AGTCAGCCAC & 60 & 35.0 \\
OPA-04 & AATCGGGCTG & 60 & 35.1 \\
OPA-05 & AGGGGTCTTG & 60 & 32.6 \\
OPA-06 & GGTCCCTGAC & 70 & 35.2 \\
OPA-07 & GAAACGGGTG & 60 & 33.2 \\
OPA-08 & GTGACGTAGG & 60 & 31.1 \\
OPA-09 & GGGTAACGCC & 70 & 37.4 \\
OPA-10 & GTGATCGCAG & 60 & 33.1 \\
OPA-11 & CAATCGCCGT & 60 & 36.7 \\
OPA-12 & TCGGCGATAG & 60 & 34.0 \\
OPA-13 & CAGCACCCAC & 70 & 37.7 \\
OPA-14 & TCTGTGCTGG & 60 & 34.3 \\
OPA-15 & TTCCGAACCC & 60 & 34.2 \\
OPA-16 & AGCCAGCGAA & 60 & 38.3 \\
OPA-17 & GACCGCTTGT & 60 & 35.7 \\
OPA-18 & AGGTGACCGT & 60 & 36.2 \\
OPA-19 & CAAACGTCGG & 60 & 34.2 \\
OPA-20 & GTTGCGATCC & 60 & 33.5 \\
\hline
\end{tabular}

young EMS-induced mutants and wild-type soybean leaf on 60 days after transplant were taken for DNA extraction and genetic test in Molecular Biology Laboratory of State Islamic University of Maulana Malik Ibrahim, Malang.

\section{DNA extraction}

About $0.1 \mathrm{~g}$ of young soybean leaf was used for DNA extraction. DNA whole genome was extracted with the Qiagen DNeasy Plant Mini Kit (Promega $^{\mathrm{TM}}$ ) following its manual instruction. DNA yields were confirmed qualitatively using electrophoresis separation on $1 \%$ agarose gels, stained with $2 \mu \mathrm{g} / \mathrm{ml}$ of Ethidium bromide (EtBr) in TBE buffer, then visualized under UV transilluminator. Geneon 100bp Plus Blue DNA ladder was used as a standard marker.

\section{PCR RAPD}

Twenty primers of OPA (Operon Technologies) were used for RAPD amplification. Total reaction volume for PCR RAPD was $10 \mathrm{ml}$ containing $3 \mathrm{ml}$ ddH2O, $5 \mathrm{ml}$ PCR MasterMix Thermo scientific, $1 \mathrm{ml}$ of OPA primer $(10 \mathrm{pmol})$ and $1 \mathrm{ml}$ DNA template $(5-25 \mathrm{ng})$. The PCR amplification was carried out in thermal cycler BioRad. One cycle of initial denaturation was conducted at $94{ }^{\circ} \mathrm{C}$ for 5 min, then followed by 45 cycles of denaturation for $30 \mathrm{sec}$ at $94^{\circ} \mathrm{C}$, annealing temperatures were varied each primer for $30 \mathrm{sec}$ (Table 1), the extension for 90 seconds at $72{ }^{\circ} \mathrm{C}$ and terminated by final extension for $7 \mathrm{~min}$ at $72{ }^{\circ} \mathrm{C}$.

Data analysis

The effectiveness of EMS to induce mutation in soybean seeds in this study was detected by polymorphism, clustering and distance method. The data were gathered based on the presence and the absence of amplification product bands, as shown on the agarose gel. It was scored as " 1 " for the present band and " 0 " for the absent band of each primer. The binary data matrix was then subjected to clustering and distance method using an unweighted pair group method with arithmetic mean (UPGMA) algorithm and Jaccard's coefficient similarity (Hammer et al. 2001) with PAST (Paleontological Statistics) software. The percentage of polymorphism was calculated by dividing the polymorphic bands shown by each primer with a total of scored bands $\mathrm{x} 100$. The presence of the mutation was also checked with a qualitative method by comparing the band thickness of each primer.

Polymorphism information content (PIC), effective multiplex ratio (EMR) and marker index (MI), were also performed to evaluate the effectiveness of each primer used. PIC Value for each primer was calculated with the formula: $\mathrm{PICi}=$ 2fi (1-fi), where PICi is the polymorphism information content of the primer $\mathrm{i}$, $\mathrm{fi}$ is the frequency of primer fragment that was present and 1 - $\mathrm{fi}$ is the frequency of primer fragment that was absent. EMR was calculated by using formula 
Table 2 . Analysis results of polymorphism and effectivity of RAPD primers used in this study

\begin{tabular}{ccccccc}
\hline Primer & $\mathbf{n B}$ & $\mathbf{n P B}$ & $\mathbf{P B} \mathbf{( \% )}$ & PIC & EMR & MI \\
\hline OPA-01 & 8 & 7 & 87.50 & 0.50 & 56 & 28.00 \\
OPA-02 & 4 & 4 & 100.00 & 0.41 & 16 & 6.56 \\
OPA-03 & 7 & 5 & 71.40 & 0.47 & 35 & 16.45 \\
OPA-04 & 6 & 5 & 83.30 & 0.49 & 30 & 14.7 \\
OPA-05 & 3 & 2 & 66.70 & 0.50 & 6 & 3.00 \\
OPA-06 & 3 & 2 & 66.70 & 0.30 & 6 & 1.80 \\
OPA-07 & 5 & 5 & 100.00 & 0.43 & 25 & 10.75 \\
OPA-08 & 7 & 6 & 85.70 & 0.43 & 42 & 18.06 \\
OPA-09 & 7 & 5 & 71.40 & 0.29 & 35 & 10.15 \\
OPA-10 & 7 & 7 & 100.00 & 0.47 & 49 & 23.03 \\
OPA-11 & 6 & 6 & 100.00 & 0.46 & 36 & 16.56 \\
OPA-12 & 5 & 5 & 100.00 & 0.45 & 25 & 11.25 \\
OPA-13 & 7 & 7 & 100.00 & 0.50 & 49 & 24.5 \\
OPA-14 & 4 & 4 & 100.00 & 0.50 & 16 & 8.00 \\
OPA-15 & 4 & 4 & 100.00 & 0.44 & 16 & 7.04 \\
OPA-16 & 4 & 4 & 100.00 & 0.44 & 16 & 7.04 \\
OPA-17 & 4 & 2 & 50.00 & 0.41 & 8 & 3.28 \\
OPA-18 & 6 & 6 & 100.00 & 0.23 & 36 & 8.28 \\
OPA-19 & 3 & 1 & 33.30 & 0.20 & 3 & 0.60 \\
OPA-20 & 5 & 5 & 100.00 & 0.50 & 25 & 12.50 \\
\hline Total & $\mathbf{1 0 5}$ & $\mathbf{9 2}$ & $\mathbf{1 7 1 6 . 0 7}$ & $\mathbf{8 . 4 2}$ & $\mathbf{5 3 0}$ & $\mathbf{2 3 1 . 5 5}$ \\
Average & $\mathbf{5 . 2 5}$ & $\mathbf{4 . 6 0}$ & $\mathbf{8 5 . 8 0}$ & $\mathbf{0 . 4 2}$ & $\mathbf{2 6 . 5}$ & $\mathbf{1 1 . 5 7}$ \\
\hline
\end{tabular}

Note: $\mathrm{nB}=$ Number of Band, $\mathrm{nPB}=$ Number of Polymorphic Band, $\mathrm{PB} \%=$ percentage of Polymorphic Band, $\mathrm{PIC}=$ Polimorphic Information Content, EMR=Effective multiplex ratio, and MI=Marker index.

$\mathrm{EMR}=\eta \cdot \beta$, where $\eta$ is the total number of fragments per primer and $\beta$ is the fraction of polymorphic fragments (Laurentin and Karlovsky, 2007). MI was calculated with formula MI= PIC $x$ EMR (Varshney et al. 2007). Pearson correlation test was also performed using SPSS 16.0 subjected to the values of PIC, EMR, and MI.

\section{RESULTS AND DISCUSSION}

\section{RAPD Profiles}

RAPD is a technique based on the PCR method to identify genetic variation. RAPD has been used as an assessment intraspecific variation since 1990 (Kumari and Takur, 2014). Moreover, in recent years, RAPD was also used for genetic mapping, taxonomic study and even used to detect genetic mutation in the treated plant (Dhakshanamoorthy et al. 2014). Here, we used RAPD markers to assess genetic diversity among EMS-induced soybean mutants. This study will be useful as basic information for further soybean breeding programs since it will make it easy to select where the soybean which has high genetic variation can be used for crossbreeding.
About twenty OPA primers were selected for RAPD amplification to detect polymorphism and genetic diversity among EMS soybean mutants. In total, about 105 bands were detected, in which 92 bands were considered polymorphic. Each primer generated bands ranged from 3 to 8 bands, with an average of 5.25 bands (Table 2). The minimum of 3 bands was resulted by OPA-5, OPA-6, and OPA-19 primers, whereas the maximum of 8 bands was generated by OPA-01 (Figure 1). Polymorphism percentages were ranged from $33.30 \%$ to $100 \%$, with an average of $85.80 \%$. OPA-19 showed the lowest polymorphism percentage; it only generated 1 polymorphic band out of 3 total bands (Table 2). Whilst, about 11 primers showed $100 \%$ polymorphic band percentage i.e. OPA-2, OPA-07, OPA-10, OPA-11, OPA-12, OPA-13, OPA-14, OPA-15, OPA-16, OPA-18 and OPA-20.

The values of PIC, EMR and MI can be used to identify what primer is the most informative to detect polymorphism. PIC values were varied from 0.20 to 0.50 , with an average of 0.42 . The lowest PIC value was obtained by OPA-19, whereas the highest PIC value was generated by OPA-01, OPA-05, OPA -13, OPA-14 and OPA-20 (Table 2). EMR values 


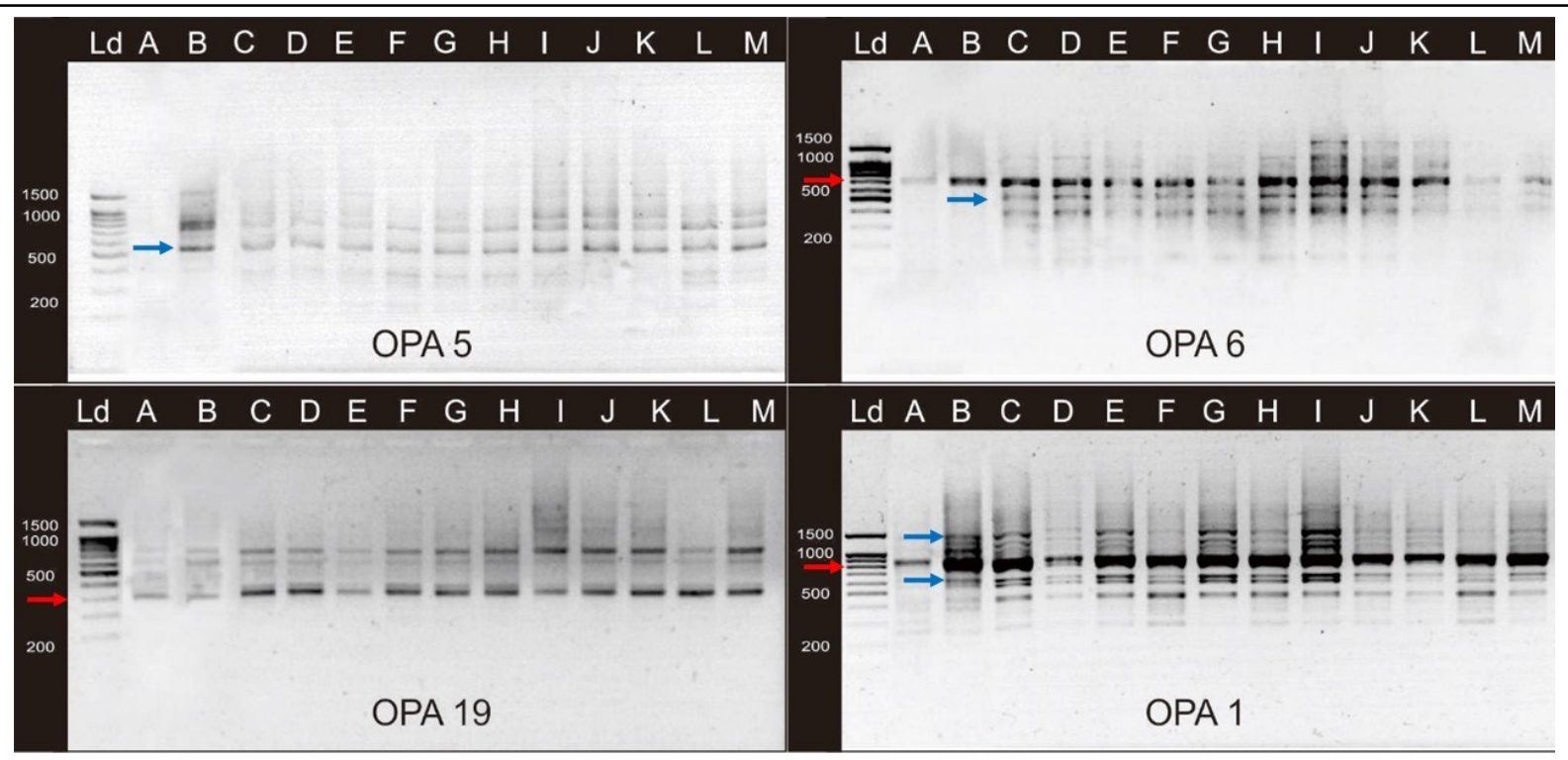

Figure 1. RAPD band profiles of the minimum bands (OPA 5, 6 and 19), a maximum band (OPA 1), the polymorphic band (blue arrow) and monomorphic band (red arrow). Ld: DNA Ladder, A \& B: control/ wild-type, C \& D: 0.5\% EMS and 4 hours incubation, E \& F: 1\% EMS and 4 hours incubation, G \& H: 0.5\% EMS and 6 hours incubation, I \& J: 1\% EMS and 6 hours incubation, K \& L: 0.5\% EMS and 8 hours incubation, M: soaked with 1\% EMS and incubated for 8 hours

were ranged from 3 to 56 , with an average of 26.5 . OPA-03 had the highest EMR value (56), whereas OPA-19 had the lowest EMR value (3). A similar tendency was also observed for the MI value. The MI values were ranged from 0.6 to 28 , with an average of 11.57. OPA-01 was observed as the highest MI value, while OPA-19 was observed as the lowest MI value (Table 2).

Polymorphism information content (PIC) was measured to evaluate the discriminatory power of the RAPD marker. PIC is determined by the ability of the primer to generate polymorphism in the population depending on their distribution frequency (Nagy et al. 2012). Thus, PIC is equivalent to genetic diversity. The maximum number of PIC for RAPD marker is 0.5 because of two alleles per locus are assumed in RAPD analysis. In this study, we found that the average PIC value was 0.421 and about $80 \%$ of the primers have PIC more than 0.4 . This fact indicated that there was genetic diversity in soybean mutant in this study caused by EMS treatment. Furthermore, the number of EMR and MI also resulted in high values. It was also indicated that EMS treatments were successfully induced high genetic variation in soybean mutants. The result of this study is similar and comparable to some previous studies in terms of mutation detection using the RAPD marker in Jatropha curcas (Dhakshanamoorthy et al. 2014), Vitis vinifera (Maia et al. 2009) and Vigna unguiculata (Kolade et al. 2016).

Some RAPD primers used in this study has detected polymorphisms among soybean mutants and wild-type. The appearance of new bands (soybean mutants) or disappearance of bands in wild -type were observed (Figure 1). The thickening band, along with EMS concentration and incubation time were also observed (Figure 2). The appearance of new bands in soybean mutants may be related to the changes in oligonucleotide priming site due to mutation, deletion and homolog recombination (Dhakshanamoorthy et al. 2014). Furthermore, Atienzar et al. (2010) revealed that only $10 \%$ mutation of one locus could emerge a new band. Therefore, in this study, EMS has successfully induced mutations on soybeans indicated by the appearance of new bands in soybean mutants assessed with RAPD markers.

The disappearance of regular bands was also detected by OPA 08 and OPA 10 primer (Figure 2). The disappearance of regular bands in soybean mutants may cause by DNA damage, modified bases, base oxidation, point mutation, and even chromosomal rearrangements induced by EMS (Dhakshanamoorthy et al. 2014). Taq polymerase can't bind DNA products due to some possible reasons including dissociation of the enzyme complex, polymerase blockage and disassociation of the enzyme complex, which may lead to the loss of the band (Atienzar and Jha, 2006). The appearance of new bands indicated the occurrence of mutations, whereas the disappearance of the band indicated the DNA damage (Dhakshanamoorthy et al. 2014). Both events were lead to genetic variations among soybean mutants compared to the wild-type. 


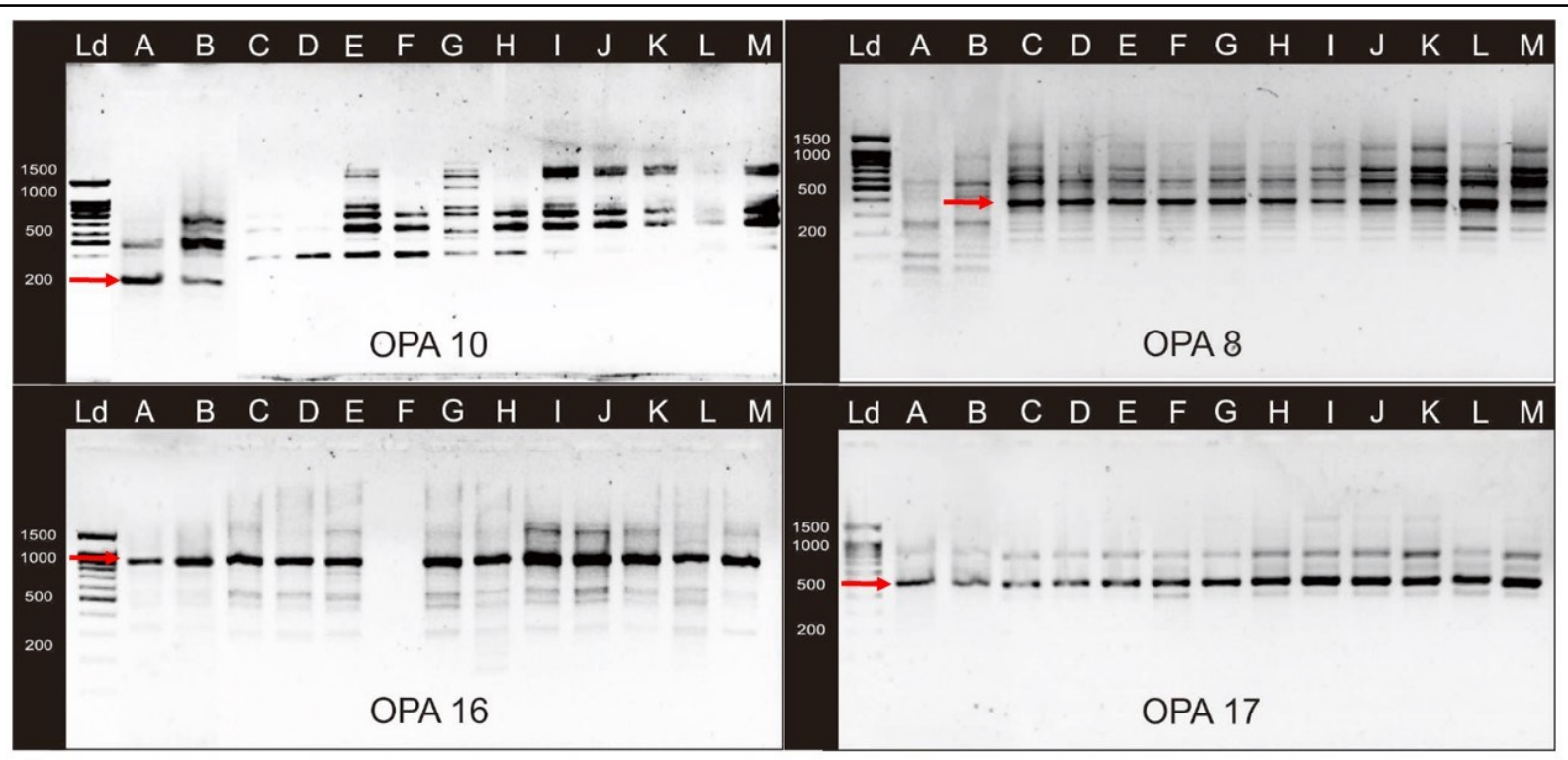

Figure 2. RAPD profiles of appearance of bands in soybean mutants (OPA 8), disappearance band in soybean mutant (OPA 10) and thickening bands along with the increasing of EMS concentration and incubation time (OPA 16 and 17). Ld: DNA Ladder, A \& B: control/ wild-type, C \& D: 0.5\% EMS and 4 hours incubation, E \& F: 1\% EMS and 4 hours incubation, $\mathrm{G} \& \mathrm{H}: 0.5 \%$ EMS and 6 hours incubation, I \& J: 1\% EMS and 6 hours incubation, $\mathrm{K} \& \mathrm{~L}: 0.5 \%$ EMS and 8 hours incubation, M: $1 \%$ EMS and 8 hours incubation.

Pearson correlation tests were performed to determine the relationships between pairs of continuous variables of PIC with EMR, PCI with MI, and EMR with MI. Result showed that there was a positive correlation between PIC with EMR ( $\mathrm{r}$ $=0.308)$ but not significant $(p=0,187>0,05)$. Whilst, PIC and MI had positive and significant correlation $(\mathrm{r}=0,529 ; \mathrm{p}=0.016<0.05)$. A positive and significant correlation $(\mathrm{r}=0.948 ; \mathrm{p}=0,000$ $<0.05$ ) were also found between EMR and MI.

In this study, we found a significant positive correlation between EMR and MI $(r=0.948$, $\mathrm{p}=0.05)$. It suggested that EMR, MI, and PIC are relevant to be used as markers for evaluation of genetic mapping and phylogenetic study (Dhakshanamoorthy et al. 2014). In addition, this study has also proved that RAPD marker is suitable for detection of genetic diversity in a breeding population (Biswas et al. 2010), as well as for mutation detection in plants (Dhakshanamoorthy et al. 2014; Kolade et al. 2016; Maia et al. 2009).

Qualitative tests based on band thickness showed that the band expression of some primers has resulted in stronger intensity with the increasing of EMS concentration and incubation time (Figure 2). The thickening bands were observed at $900 \mathrm{bp}$ of OPA-16, and OPA-17 at $500 \mathrm{bp}$ and $900 \mathrm{bp}$. Furthermore, the disappearance of the band in soybean mutants was observed by OPA 10 at 300bp and OPA 08 at 200bp (Figure 2).

Cluster analysis result

The genetic similarity among EMS-induced soybean based on RAPD marker was ranged from 0.23 to 0.84 (Table 3). All of the soybean mutants were observed to have low similarity with the wild-type. Meanwhile, it has high similarity amongst mutants. The lowest genetic similarity was observed at a pair of wild-type (A) and soybean mutants of $0.5 \%$ EMS and 6 hours incubation $(\mathrm{H})$, whereas, the highest genetic similarity was observed at a pair of soybean mutants of $1 \%$ EMS and 6 hours incubation (J) and soybean mutants of $0.5 \%$ EMS and 8 hours incubation (K).

Clustering analysis was conducted to 11 EMSinduced soybean mutants and control/ wild-type, performed using Jaccard's algorithm. One soybean mutant (1\% EMS and 8 hours incubation) was not included in the clustering analysis because the seeds cannot grow caused by the toxicity of EMS. This condition was in accordance with the result of $\mathrm{Li}$ et al. (2017) that a high concentration of EMS showed reduced emergence and physiological damage, including inhibition of the main stem even failed to grow. The dendrogram of genetic relationship resulted in 2 major groups (Figure 3). The wild-type soybean became the first group, which act like an outgroup. The second group was consist of all soybean mutants, which can be separated into 3 subgroups based on EMS concentration and incubation time. The subgroup 1 was comprised of soybean mutants generated by $0.5 \%$ EMS and $1 \%$ EMS and incubated for 4 hours and 6 hours incubation. The subgroup 2 was consists of soybean mutants generated by $0.5 \%$ EMS and 1\% EMS for 6 hours and 8 hours incubation. The subgroup 3 was 
Table 3. Jaccard's coefficient similarity among EMS induced soybean mutants and wild-type

\begin{tabular}{|l|r|r|r|r|r|r|r|r|r|r|r|r|r|}
\hline & $\mathbf{A}$ & $\mathbf{B}$ & $\mathbf{C}$ & $\mathbf{D}$ & $\mathbf{E}$ & $\mathbf{F}$ & $\mathbf{G}$ & $\mathbf{H}$ & $\mathbf{I}$ & $\mathbf{J}$ & $\mathbf{K}$ & $\mathbf{L}$ & $\mathbf{M}$ \\
\hline $\mathbf{A}$ & - & & & & & & & & & & & & \\
\hline $\mathbf{B}$ & 0.63 & - & & & & & & & & & & & \\
\hline $\mathbf{C}$ & 0.25 & 0.39 & - & & & & & & & & & & \\
\hline $\mathbf{D}$ & 0.31 & 0.42 & 0.77 & - & & & & & & & & & \\
\hline $\mathbf{E}$ & 0.29 & 0.42 & 0.75 & 0.76 & - & & & & & & & & \\
\hline $\mathbf{F}$ & 0.32 & 0.37 & 0.67 & 0.69 & 0.74 & - & & & & & & & \\
\hline $\mathbf{G}$ & 0.27 & 0.42 & 0.65 & 0.65 & 0.74 & 0.67 & - & & & & & & \\
\hline $\mathbf{H}$ & 0.23 & 0.36 & 0.76 & 0.77 & 0.73 & 0.70 & 0.59 & - & & & & & \\
\hline $\mathbf{I}$ & 0.24 & 0.40 & 0.75 & 0.66 & 0.76 & 0.62 & 0.68 & 0.61 & - & & & & \\
\hline $\mathbf{J}$ & 0.30 & 0.40 & 0.76 & 0.79 & 0.75 & 0.69 & 0.69 & 0.67 & 0.80 & - & & & \\
\hline $\mathbf{K}$ & 0.28 & 0.39 & 0.72 & 0.74 & 0.72 & 0.62 & 0.63 & 0.59 & 0.78 & 0.84 & - & & \\
\hline $\mathbf{L}$ & 0.38 & 0.42 & 0.63 & 0.67 & 0.63 & 0.79 & 0.65 & 0.62 & 0.57 & 0.65 & 0.60 & - & \\
\hline $\mathbf{M}$ & 0.30 & 0.42 & 0.69 & 0.69 & 0.70 & 0.66 & 0.64 & 0.59 & 0.79 & 0.83 & 0.78 & 0.64 & - \\
\hline
\end{tabular}

Note: A \& B: control/ wild-type, C \& D: 0.5\% EMS and 4 hours incubation, E \& F: $1 \%$ EMS and 4 hours incubation, G \& H: 0.5\% EMS and 6 hours incubation, I \& J: 1\% EMS and 6 hours incubation, K \& L: 0.5\% EMS and 8 hours incubation, M: $1 \%$ EMS and 8 hours incubation.

consists of the mixture of soybean mutants generated by $0.5 \%$ EMS and $1 \%$ EMS for 4 hours, 6 hours and 8 hours incubation.

The similarity index and clustering method were performed to ascertain the degree of genetic relationship among soybean mutants and wild-type. The lowest similarity index was observed by a pair of wild-type and soybean mutants from treatments of $0.5 \%$ EMS and incubated for 6 hours (similarity index $=0.23$ ). It was indicated that those treatments generated soybean mutants with the highest genetic distance compare to the wild-type. Whilst, the highest similarity index was observed by soybean mutants with $1 \%$ EMS and incubated for 6 hours and soybean mutants with $0.5 \%$ EMS and incubated for 8 hours (similarity index $=0.59$ ). It was indicated that both treatments resulted in quite similar soybean mutants with low genetic distance. Moreover, this study was proven that EMS treatments successfully resulted in the potential variation among soybean mutants compared to the wild-type. It was supported by dendrogram which showed different clustering between wild-type and soybean mutants, and also amongst soybean mutants in different concentrations of EMS and incubation time.

EMS is an effective mutagen which caused transitions of DNA bases $\mathrm{G} / \mathrm{C}$ to $\mathrm{A} / \mathrm{T}$ (Greene et al. 2003). Therefore, it was led to a mispairing of complementary bases and caused a high frequency of gene mutation (Behera et al. 2012). EMS has been widely used as genetic variability induction in several plants like Asteranctha longifolia (Behera et al. 2012), Vigna unguiculata (Girija et al. 2013), Cucumis sativus (Wang et al. 2014) and Jatropha curcas (Dhakshanamoorthy et al. 2014). In this study, EMS was also proven to induce genetic variability in the soybean plant.

Another method that can be used to increase the genetic variability of soybean is somatic embryogenesis (somatoclone). This method utilizes the polyethylene glycol (PEG) as an osmotic solution. Somotoclone method has been proven to derived new varieties of soybean that tolerance against drought stress (Sunaryo et al. 2016). However, this technology requires a high cost and advance tool that makes it difficult to be implemented by the farmer.

RAPD marker effectively detected variability and have been adopted in a population study, plant systematic (Arif et al. 2010) and plant breeding (Fei et al. 2014). Moreover, it has some other advantages such as it is applicable for anonymous genome, low DNA quantities and resulted in a high number of DNA fragments (Kumari and Thakur, 2014). However, it has some disadvantages regarding their low sensitivity and reproducible, which caused unstable results; the different study will result in a different outcome. In spite of the contrary argument regarding their usage for genetic diversity study, 


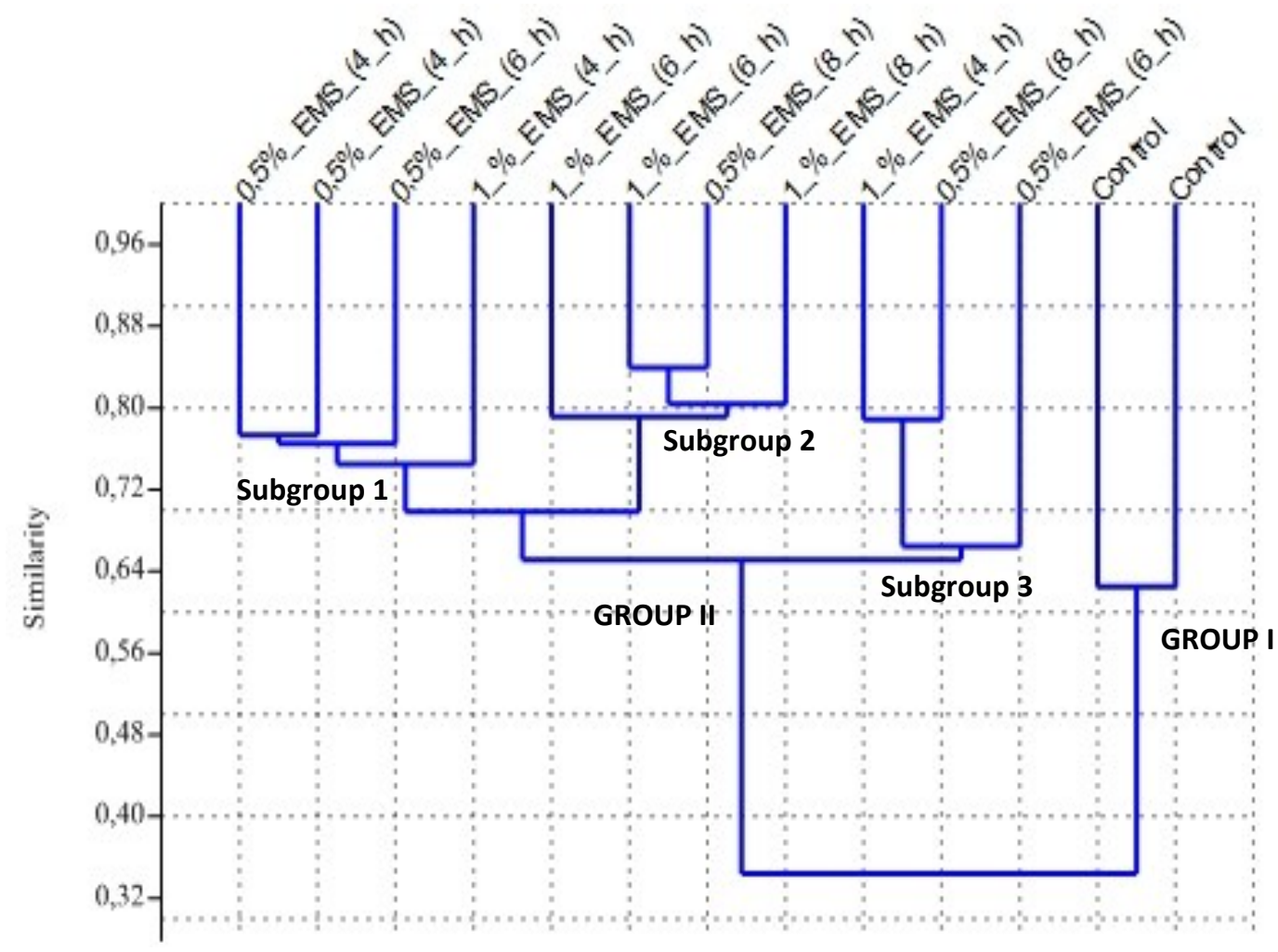

Figure 3. Dendrogram generated from Jaccard's coefficient similarity showing the genetic relationship of 11 EMS induced soybean mutants and control/ wild-type.

RAPD was still recommended and acceptable for detecting genetic variability than AFLP, ISSR and SSR (Sun and Wong, 2001).

\section{CONCLUSION}

EMS was an effective chemical mutagen to induce potential mutations in soybean. In this study, RAPD marker is still applicable and relevant to detect genetic mutations while also can be used as an alternative genetic approach. The occurrence of mutations in this study was shown by genetic variability, clustering and band appearance that all of them were obtained by RAPD marker.

\section{ACKNOWLEDGMENTS}

This work was supported by a grant from the Faculty of Science and Technology, State Islamic University of Maulana Malik Ibrahim, Malang, Indonesia. The authors thank Rasyadan Taufiq and Ahmad Affan Ali Murtadlo for helping us in the laboratory for collecting data.

\section{REFERENCES}

Aisyah, S.I., Hapsari L. \& Herlina, D., 2005, Induced mutation on jasmine (Jasminum spp.) through gamma irradiation, Journal of Agriculture and Rural Development in the Tropics and Subtropics Beheift 83, 120 - 127.
Arif, I.A., Bakir, M.A., Khan, H.A., Al Farhan, A.H., Al Homaidan, A.A., Bahkali, A.H.,. Al Sadoon M. \& Shobrak M., 2010, Application of RAPD for molecular characterization of plant species of medicinal value from an arid environment, Genetics and Molecular Research 9, 2191-2198.

Ashraf, M., Cheema, A.A., Zia-Ul-Qamar \& Rashid M., 2007, Detection of Polymorphism In Rice Germplasm Using RAPD Marker, Pakistan Journal of Botany 39, 2483-2493.

Atienzar, F.A., Conradi, M., Evenden, A.J., Jha, A.N. \& Depledge M.H., 2010, Qualitative assessment of genotoxicity using random amplified polymorphic DNA: comparison of genomic template stability with key fitness parameter in Daphnia magna exposed to benzo[a] pyrene, Environmental Toxicology and Chemistry 18, 2275-2282.

Atienzar, F.A. \& Jha A.N., 2006, The random amplified polymorphic DNA (RAPD) assay and related techniques applied to genotoxicity and carcinogenesis studies: A critical review, Mutation Research 613, 76-102.

Balitbangtan, 2005, Prospek dan Arah Pengembangan agribısnis kedelai, Departemen Pertanian RI, Jakarta.

Balitbangtan, 2016, Grobogan, Panen Kedelai 3 ton/ha, Viewed July 11, 2018, from http:// www.litbang.pertanian.go.id/press/one/49/ pdf/Grobogan, $\% 20$ Panen $\% 20$ Kedelai $\% 203 \%$ 20ton/ha.pdf. 
Balitkabi, 2016, Deskripsi Varietas Unggul Aneka Kacang dan Umbi. Balai Penelitian Tanaman Aneka Kacang dan Umbi, Badan Penelitian dan Pengembangan Pertanian, Kementerian Pertanian Republik Indonesia, Jakarta.

Behera, M., Panigrahi, J., Mishra, R.R. \& Rath S.P., 2012, Analysis of EMS induced in vitro mutants of Asteranctha longifolia (L.) Nees using RAPD Markers, Indian Journal of Biotechnology 11, 39-47.

Biswas, M.K., Xu, Q. \& Deng, X-X., 2010, Utility of RAPD, ISSR, IRAP and REMAP markers for the genetic analysis of Citrus spp., Scientia Horticulturae 124, 254-261.

Daryono, B.S., Aristya, G.R. \&. Kasiamdari, R.S., 2011, Development of Random Amplifed Polymorphism DNA Markers Linked to Powdery Mildew Resistance Gene in Melon, Indonesian Journal of Biotechnology 16, 76-82.

Dhakshanamoorthy, D., Selvaraj, R. \& Chidambaramb, A., 2014, Utility of RAPD marker for genetic diversity analysis in gammarays and ethyl methane sulphonate (EMS)-treated Jatropha curcas plants, Comptes Rendus Biologies 338, 75-82.

Fei, Y., Tang, W., Shen, J., Tianjing, Z., Rui, Q., Xiao, B., Zhou, C., Liu, Z. \& Anna, Y.T., 2014, Application of random amplified polymorphic DNA (RAPD) markers to identify Taxus chinensis var. mairei cultivars associated with parthenogenesis, African Journal of Biotechnology 13, 2385-2393.

Garcia, V., Bres, C., Just, D., Fernandez, L., Tai, F.W., Mauxion, J.P., Le Paslier, M.C., Bérard, A., Brunel, D., Aoki, K., Alseekh, S., Fernie, A.R., Fraser, P.D. \& Rothan, C., 2016, Rapid identification of causal mutations in tomato EMS populations via mapping-by-sequencing, Nature Protocols 11, 2401-2418.

Girija, M., Dhanavel, D. \& Gnanamurthy, S., 2013, Gamma rays and EMS induced flower color and seed mutants in cowpea (Vigna unguiculata L. Walp), Advances in Applied Science Research 4, 134-139.

Greene, E.A., Codomo, C.A., Taylor, N.E., Henikoff, J.G., Till, B.J., Reynolds, S.H., Enns, L.C., Burtner, C., Johnson, J.E., Odden, A.R., Comai, L. \& Henikoff, S., 2003, Spectrum of Chemically Induced Mutations From a LargeScale Reverse-Genetic Screen in Arabidopsis, Genetics 164, 731-740.

Hammer, Ø., Harper, D.A.T. \& Ryan, P.D., 2001, PAST: Paleontological Statistics Software Package for Education and Data Analysis. Palaeontol, Palaeontologia Electronica 4, 1-9.
Kawar, P.G., Devarumath, R.M. \& Nerkar Y., 2009, Use of RAPD Marker for assessment of Genetic Diversity in Sugarcane cultivar, Indian Journal of Biotechnology 8, 67-71.

Khan, M.H. \& Tyagi, S.D., 2013, A review on induced mutagenesis in soybean, Journal of Cereals and Oilseeds 4, 19-25.

Khan, M.H. \& Tyagi, S.D., 2010, Induced morphological mutants in soybean [Glycine max (L.) Merrill], Frontiers of Agriculture in China 4, 175-180.

Kolade, O.A., Olowolafe, M.O. \& Fawole, I., 2016, Characterization of mutant cowpea [Vigna unguiculata (L) Walp] lines using random amplified polymorphic DNAs (RAPDs) and amplified fragment length polymorphism (AFLP) markers, African Journal of Biotechnology 15, 2530-2537.

Krisdiana, R., 2013, Penyebaran Varietas Unggul Kedelai dan Dampaknya terhadap Ekonomi Perdesaan, Peneltian Pertanian Tanaman Pangan 33, 61-69.

Kristanti, N.E., Rahmawati, F. \& Maksum, M., 2017, Analysis of Productivity of Soybean [Glycine $\max ($ L.) Merr.] for Production for Farmers in Indonesia, Proceedings of The $3 \mathrm{rd}$ International Conference on Agro-Industry 2016 "Competitive \& Sustainable AgroIndustry: Value Creation in Agribusiness" (3rd IcoA 2016), Bangkok, Thailand, pp. 237-246.

Kumari, N. \& Thakur, S.K., 2014, Randomly Amplified Polymorphic DNA-a Brief Review, American Journal of Animal and Veterinary Sciences 9, 6-13.

Laurentin, H. \& Karlovsky, P., 2007, AFLP fingerprinting of sesame (Sesamum indicum L.) cultivars: identification, genetic relationship and comparison of AFLP informativeness parameters, Genetic Resources and Crop Evolution 54, 1437-1446.

Li, Z., Jiang, L., Ma, Y., Wei, Z., Hong, H., Liu Z., Lei, J., Liu, Y., Guan, R., Guo. Y., Jin, L., , Zhang, L., Li, Y., Ren, Y., He, W., Liu, M., Htwe, N.M.P.S., Liu, L., Guo, B., Song, J., Tan, B., Liu, G., Li, M., Zhang, X., Liu, B., Shi X., Han, S., Hua, S., Zhou, F., Yu, L., Li., Y., Wang, S., Wang, J., Chang, R., \& Qiu, L., 2017, Development and utilization of a new chemically-induced soybean library with a high mutation density, Journal of Integrative Plant Biology 59(1), 60-74

Maia, S.H.Z., Mangolin, C.A., Collet, S.A. \& Machado, M.F., 2009, Machado Genetic diversity in somatic mutants of grape (Vitis vinifera) cultivar Italia based on random amplifed polymorphic DNA, Genetics and Molecular Research 8, 28-38. 
Mishra, K.K., Fougat, R.S., Ballani, A., Thakur, V., Jha, Y. \& Bora, M., 2014, Potential and application of molecular markers techniques for plant genome analysis, International Journal of Pure \& Applied Bioscience 2, 169-188.

Nagy, S., Poczai, P., Cerna'k, I., Gorji, A.M., Hegedus, G. \& Taller J., 2012, PICcalc: An Online Program to Calculate Polymorphic Information Content for Molecular Genetic Studies, Biochemical Genetics 50, 670-672.

Nikmah, I.A., Azrianingsih, R., Wahyudi, D., 2016. Genetic diversity of porang populations (Amorphophallus muelleri Blume) in Central Java and West Java based on LEAFY second intron marker, Journal of Tropical Life Science 6 (1), 2327.

Oladosu, Y., Rafii, M.Y., Abdullah, N., Hussin, G., Ramli, A., Rahim, H.A., Miah, G. \& Usman M., 2016, Principle and application of plant mutagenesis in crop improvement: a review, Agriculture and Environmental Biotechnology 30, 116.

Pusdatin, 2015, Outlook Komoditas Pertanian Tanaman Pangan Kedelai, Kementerian Pertanian RI, Jakarta.

Rahajeng, W. \& Adie, M.M., 2013, Varietas kedelai umur genjah, Buletin Palawija 26, 91-100.

Setiawan A, 2013, RI Belum Lepas Ketergantungan Impor Kedelai Tabun Ini, viewed March 3, 2018 from: http://finance.detik.com/read/.

Shah, T.M., Mirza, J.I., Haq, M.A. \& Atta, B.M., 2009, Screening of chickpea (Cicer arietinum) induced mutants against Fusarium wilt, Pakistan Journal of Botany 41, 1945-1955.

Singh, G., Sareen, P.K, Saharan, R.P. \& Singh, A., 2001, Induced variability in mungbean (Vigna radiata L), Indian Journal of Genetics and Plant Breeding. 61, 281-282.

Soeranto, H., Manurung, S. \& Masrizal, 2001, The use of physical/chemical mutagens for crop improvements in Indonesia, Proceedings of the 8 th workshop on plant mutation breeding, Japan, pp. 90-101.

Sreeju, S.N., Babu, M.M., Mariappan, C. \& Selvamohan, T., 2011, Effect of physical and chemical mutagens on biopolmer producing strains and RAPD analysis of mutated strains, Archives of Applied Science Research 3, 233-246.
Sunaryo, W., Widoretno, W., Nurhasanah \&

Sudarsono, 2016, Drought tolerance selection of soybean lines generated from somatic embryogenesis using osmotic stress simulation of poly-ethylene glycol (PEG), Nusantara Bioscience 8, 45-54.

Suherman M, 2014, Optimis Tiga Tahun Swasembada Kedelai, Viewed July 7, 2018, from: http:// agroindonesia.co.id/2014/11/18/optimis-tigatahun-swasemba da-kedelai.

Sun, M. \& Wong, K.C., 2001, Genetic structure of three orchid species with contrasting breeding systems using RAPD and allozyme markers, American Journal of Botany 88, 2180-2188.

Sundari, Arumingtyas, E.L., Hakim, L., Azrianingsih, R. and Wahyudi D., 2017, Genetic variability of Local Durian (Durio zibethinus murr.) In Ternate Island Based on Rapd Markers, Plant Cell Biotechnology and Molecular Biology 18, 68-75.

Thilagavathi, C. \& Mullainathan L., 2009, Isolation of Macro Mutants and Mutagenic Effectiveness, Efficiency in Black Gram (Vigna mungo (L.) Hepper), Global Journal of Molecular Sciences 4(2), 76-79.

Varshney, R.K., Chabane, K., Hendre, P.S., Aggarwal, R.K. \& Graner A., 2007, Comparative assessment of EST-SSR, ESTSNP and AFLP markers for evaluation of genetic diversity and conservation of genetic resources using wild, cultivated and elite barleys, Plant Science 173, 638-649.

Wahyudi, D., Azrianingsih, R., \& Mastuti, R., 2013, Genetic variability of Porang Populations (Amorphophallus muelleri) in West Java and Central Java Based on TrnL İntron Sequences. Journal of Biodiversity and Environmental Sciences 3, $31-41$.

Wang, L., Zhang, B., Li, J., Yang, X. \& Ren, Z., 2014, Ren Ethyl Methanesulfonate (EMS)Mediated Mutagenesis of Cucumber (Cucumis sativus L.), Agricultural Sciences 5, 716-721.

Wulandari, S.S., 2016, Kebijakan Pemerintah Indonesia Dalam Melindungi Petani Lokal Dari Ancaman Impor Kedelai Amerika Serikat Tahun 2012-2016, JOM FISIP 4, 1-15. 